Parameter optimization for thermostable lipase production and performance evaluation as prospective detergent additive

Authors: Sahoo, R.K., Das, A., Gaur, M., Sahu, A., Sahoo, S., Dey, S., Rahman, PKSM. \& Subudhi, E.

Keywords: Response surface methodology, solid state fermentation, lipase, oil-cake, Anoxybacillus $\mathrm{sp}$, detergents additive 


\title{
Parameter optimization for thermostable lipase production and performance evaluation as
}

\section{prospective detergent additive}

\begin{abstract}
Lipase based formulations has been a rising interest to laundry detergent industry for their ecofriendly property over phosphate-based counterparts and compatibility with chemical detergents ingredients. A thermo-stable Anoxybacillus sp. ARS-1 isolated from Taptapani Hotspring, India was characterized for optimum lipase production employing statistical model central composite design (CCD) under four independent variables (temperature, $\mathrm{pH}, \%$ moisture and bio-surfactant) by solid substrate fermentation (SSF) using mustard cake. The output was utilized to find the effect of parameters and their interaction employing response surface methodology (RSM). A quadratic regression with $\mathrm{R}^{2}=0.955$ established the model to be statically best fitting and a predicted highest lipase production of $29.4 \mathrm{IU} / \mathrm{g}$ at an optimum temperature of $57.5^{\circ} \mathrm{C}, \mathrm{pH} 8.31$, moisture $50 \%$ and $1.2 \mathrm{mg}$ of bio-surfactant. Experimental production of $30.3 \mathrm{IU} / \mathrm{g}$ lipase at above conditions validated the fitness of model. Anoxybacillus sp. ARS-1 produced lipase was found to resist almost all chemical detergents as well as common laundry detergent, proving it to be a prospective additive for incorporation.
\end{abstract}

Keywords: Response surface methodology; solid state fermentation; lipase; oil-cake; Anoxybacillus sp.; detergents additive 


\section{Introduction}

Lipase is the second largest commercially produced enzyme used in various industries for the production of fine chemicals, cosmetics, pharmaceuticals and biodiesel including detergents. ${ }^{[1]}$ More than thousands of tons of lipase has been used for the production of laundry detergents as an additive or to replace the chemical detergents because of its advantage of being eco-friendly and better ability to remove oil stains with not harming the texture of the cloth. ${ }^{[2,3]}$ The value of lipase producing industry was estimated to reach 1.8 billion dollars by 2018 and expected to be much more by now. ${ }^{[4]}$ Commercially used lipase is found to be stable under high $\mathrm{pH}$ and temperature and should be unaffected in the presence of other detergents, oxidizing EgGehtseand slipfexctan\$s dtergents additive has been reported several species of Bacillus and Bulkhoderia. ${ }^{[6-8]}$ However, reduction of the cost of biotechnologically produced lipases has always been a challenge, despite its extensive reports on production and use. High cost incurring media components are the common constraints which compels to search for low-cost solid substrates. ${ }^{\text {[4] }}$ Further methodological up-gradation through solid substrate fermentation (SSF) is preferred over traditional submerged fermentation (SMF) for its economic benefits. [9]

Waste biomass from oil seed industries are left with rich residual nutrients even after the extraction of oil, which has been popularly used as solid substrate among all other agro-industrial waste. It acts as a very good resource for growth of microbes to produce enzymes. ${ }^{[10]}$ Bacterial lipase has been successfully produced using oil industry waste following solid state fermentation. [11-14] According to NMOOP's (National Mission on Oilseeds and Palm) mission statement, current Indian fiscal year term targets (IFY 2017/18 to IFY 2021/22) for the production of oilseeds and oil 
meals has been 42.1 and 19.0 million metric tons (MMT) annually of which mustard contributes 9.75 and 3.2 MMT respectively. ${ }^{[15]}$

Various physical parameters like temperature, $\mathrm{pH}$, moisture content and surfactants play an important role in interacting among themselves and influencing the lipase production when such solid wastes are used in fermentation process. ${ }^{[16-19]}$ In order to dispense with the influence and interaction of more than one physical parameters during lipase fermentation, central composite design (CCD), and response surface methodology (RSM) statistical models were employed. ${ }^{[20,21]}$ Optimization of lipase production in vitro using mathematical prediction models before scaleup is a justified method employed here.

Therefore, in the present study, we investigated and characterized the lipase produced by an alkali tolerant thermophilic isolate Anoxybacillus sp ARS1 from a tropical hot spring Taptapani, Odisha, India using mustard oil cake by solid substrate fermentation. We further assayed the compatibility of the lipase produced to different surfactants, few oxidizing agents as well as in the presence of other commercially available laundry detergents.

\section{Materials and methods}

\section{Materials}

The oil cakes used in the present work were collected from oil producing company of the locality. Specific reagents like; p-nitrophenyl laureate was supplied by Sigma-Aldrich Chemicals, India and other routine reagents were from HIMEDIA (Mumbai, India).

\section{Development of lipase producing consortia}

Soil sample was collected from Taptapani hotspring and inoculated in Bushnell Haas Broth (BHB) supplemented with $1 \%(\mathrm{v} / \mathrm{v})$ olive oil and incubated for $72 \mathrm{~h}$ at $50{ }^{\circ} \mathrm{C}$. After $72 \mathrm{~h}, 5 \mathrm{ml}$ from the flask was transferred into fresh BHB olive oil medium to develop aerobic consortia. The process 
was repeated for another two weeks at interval of $72 \mathrm{~h}$ to acclimatize the microbes for oil utilization.

\section{Isolation and screening of lipase producing bacteria}

The developed consortium was plated on Bushnell Haas agar medium supplemented with olive oil $(0.5 \% \mathrm{v} / \mathrm{v})$ and Rhodamine $\mathrm{B}(0.01 \% \mathrm{w} / \mathrm{v})$ and incubated at $50{ }^{\circ} \mathrm{C}$ for $72 \mathrm{~h}$. After $72 \mathrm{~h}$, the colonies showing halo zone under UV light were picked and inoculated in $\mathrm{BHB}+$ olive oil $(0.5 \% \mathrm{v} / \mathrm{v})$ to determine their ability to produce lipase. After $72 \mathrm{~h}$ incubation, cells were separated by centrifugation and supernatant was used as crude lipase and it was assayed by spectrophotometric method by using 4-nitrophenyl laurate as a substrate described by Sahoo et al ${ }^{[22]}$. One unit (IU) of lipase was defined as the amount of enzyme that liberate one micro-mole of 4-nitrophenol per minute under assay condition.

\section{Molecular identification of lipase producing bacteria}

Genomic DNA of selected bacteria was extracted by using DNeasy ultraclean microbial kit (Qiagen, India). 16S rRNA gene was amplified by using universal primers 8F (5'AGAGTTTGATCCTGGCTCAG-3') and 1492R (5'-GGTTACCTTGTTACGACTT-3'). $25 \mu 1$ of PCR reaction mixture contained $12.5 \mu \mathrm{l}$ of PCR master mix (2X) (Thermo Fisher Scientific, India) and $1 \mu 1$ of each forward and reverse primer $(10 \mu \mathrm{M} / \mu \mathrm{l})$. Temperature profiles for PCR reaction was followed: 35 cycles of $94{ }^{\circ} \mathrm{C}(60 \mathrm{~s}), 55^{\circ} \mathrm{C}(45 \mathrm{~s})$ and $72{ }^{\circ} \mathrm{C}(60 \mathrm{~s})$ with initial denaturation at $94^{\circ} \mathrm{C}(3 \mathrm{~min})$ and final extension at $72^{\circ} \mathrm{C}(10 \mathrm{~min})$. PCR product was sequenced by AgriGenome Labs Pvt Ltd, India and analyzed through NCBI's BLAST tool. ${ }^{[23]}$ The 16 S rRNA gene sequence of bacterial strain was submitted in the GeneBank database (Gene bank accession number KR606390). The phylogenetic tree was constructed by retrieving 16S rRNA gene of already 
reported lipase producing Anoxybacillus species using MEGA v6.0 ${ }^{[24]}$ with 1000 bootstrap replicates.

\section{Process optimization for lipase production using CCD}

CCD was followed in order to find the most suitable conditions for synthesis of lipase enzyme through solid substrate fermentation as well as for the identification of variables controlling it. The parameters were optimized using the mathematical model following RSM to quantify their substantial influence on lipase production and to evaluate the existing interaction among them. Production of lipase (IU/g) was considered as a dependent response variable whereas A (Temperature ${ }^{\circ} \mathrm{C}$ ), $\mathrm{B}(\mathrm{pH}), \mathrm{C}$ (Moisture \%) and $\mathrm{D}$ (biosurfactant in $\mathrm{mg}$ ) were taken as independent variables. Table 1 represents the range and levels for different variables.

\section{Validation of prediction model}

In order to find the goodness of fit of the employed model, the experimental lipase production was compared with the predicted lipase quantity under model predicted parameters such as, temperature $57.5{ }^{\circ} \mathrm{C}, \mathrm{pH} 8.31$, moisture $50 \%$, bio-surfactant $1.2 \mathrm{mg}$ using mustard cake and Anoxybacillus sp. following SSF.

\section{Solid state fermentation (SSF) Experiment}

The SSF experiment was carried out in $250 \mathrm{ml}$ of conical flasks containing $10 \mathrm{~g}$ of Mustard oil cakes and Anoxybacillus sp. $\left(10^{8} \mathrm{CFU} / \mathrm{ml}\right)$. Biomass without culture served as control. All the flasks were incubated $120 \mathrm{~h}$ and measured lipase activity every $24 \mathrm{~h}$. After regular interval, $0.1 \mathrm{gm}$ of biomass was resuspended with $1 \mathrm{ml}$ sterile water and centrifuged at 10,000 rpm for $10 \mathrm{~min}$. The cell free extract was used as crude lipase. Lipase activity was measured as described by ${ }^{[22]}$ Effect of chemicals and commercial detergents 
The compatibility and stability study of crude lipase with chemical detergents (Tween 20, Tween 80, Triton X 100, SDS and CTAB) and commercial detergents (Surf excel, Ghadi, Wheel, Ariel and Ezee) were determined by preincubating the mixture of crude enzyme and detergents (each at $1 \% \mathrm{w} / \mathrm{v}$ ) for $1 \mathrm{~h}$.

\section{Statistical analysis}

The analysis of variance (ANOVA) was used for statistical analysis. The associated probability $p(F)$ and the degree of fit to the regression model were determined by Fisher's test (F-test) and coefficients $\left(\mathrm{R}\right.$ and $\mathrm{R}^{2}$ ) to establish the significance of the model. Graphical examination of influence of independent process variables on the experimental results were studied from twodimensional contour plots and three-dimensional response surface curves using Design-Expert ${ }^{\circledR}$ Software Version 6.0.7 (Stat-Ease Inc, Minneapolis, USA).

\section{Result and discussion}

\section{Consortium analysis}

In this study, the aerobic consortium was developed by augmentation technique using olive oil as the sole source of carbon. After $72 \mathrm{~h}$ of incubation, the bacterial consortium produced $22.7 \mathrm{U} / \mathrm{ml}$ of lipase. Twelve isolates (ARS-1 to ARS-12) were obtained from the consortium by spreading on BHA + olive oil + Rhodamine B Plate produced orange halo zones under UV light. After $72 \mathrm{~h}$ of incubation in BHB medium supplemented with olive oil, 12 isolates (ARS-1 to ARS-12) showed lipase activity ranging from $3.89 \mathrm{U} / \mathrm{ml}$ to $19.26 \mathrm{IU} / \mathrm{ml}$ (Fig. 1) and the highest activity was exhibited by ARS- 1 .

16S rRNA gene sequencing of the most efficient lipase producer (ARS-1) showed $99 \%$ similarity with Anoxybacillus species and was named as Anoxybacillus sp. ARS-1. Phylogenetic tree of Anoxybacillus sp. ARS-1 was constructed based on the 16S rRNA gene with reported lipase 
producing Anoxybacillus species. The tree showed Anoxybacillus sp. ARS-1 was phylogenetically distinct from other lipase-producing species of Anoxybacillus (Fig. 2). Olusesan et al. (2009) [25] reported the range of lipase production to be 0.56 to $2.62 \mathrm{U} / \mathrm{ml}$ and the highest being by a species of Anoxybacillus. However, another Anoxybacillus species isolated from thermophilic environment (Bakir and Metin 2016) ${ }^{[26]}$ produced a higher amount of lipase (51 U/mg).

\section{Effect of parameters on lipase production}

As designed by $\mathrm{CCD}, 30$ different batch runs under various parametric conditions were performed of which 16,8 and 6 points were respectively assigned to factorial, axial and center points. The experimental and predicted production of lipase enzyme (IU/g) was given in Table 2. The principal effect of variable parameters like; moisture, biosurfactant and temperature were found to be remarkable and that of $\mathrm{pH}$ was quadratic as found from the Fisher F-test. The quadratic model of response surface was analyzed by using ANOVA (Table S3). The $p$ value is $<0.0001$, which indicate that model is significant and confirmed by $\mathrm{F}$ value (3251.927). From the ANOVA analysis, the $\mathrm{pH}$ with high $\mathrm{F}$ value (142.522) has indicated the crucial factor for lipase production. Similarly, effect of $\mathrm{pH}$ with high $\mathrm{F}$ value (15939.05) on lipase production was observed in Ochrobactrum intermedium MZV101 lipase ${ }^{[27] .}$

Among all the variables, $\mathrm{pH}$ was found to be highly interactive with others significantly and thus considered for the model equation at higher order (Eq. 1). F value at $99.99 \%$ confidence level establishes the significance of the model. The regression analysis having the value of $\mathrm{R}^{2}$ to be 0.955 indicates the quadratic model as best fitting with the experimental data and the value of the coefficient of variation at 6.9 establishes that the experiments are reliable.

Y representing the lipase enzyme activity for MOC as shown by the model equation (Eq. 1) where temperature, $\mathrm{pH}$, moisture and biosurfactant are represented as $\mathrm{A}, \mathrm{B}, \mathrm{C}$ and $\mathrm{D}$ respectively. 
$Y=-348.9+0.24 A+59.6 B+4.8 C+3.18 D+1.3 A 2-3.636 B 2-0.047 C 2-8.68 D 2-$

$029 A B+0.020 A D+2.052 B \ldots \ldots \ldots \ldots . . . . . .1$

The lipase activity (Y) has been predicted from the above equation (1) and presented in Table 1. The predicted average percentage absolute error was found to be $5.8 \%$ (Data not given) which was within the acceptable limit and thus chosen model could be employed for optimization of parameter for the highest lipase production.

Statistical software Design-Expert v6.0 (State-Ease Inc., Minneapolis, USA) was used to generate graphs; the contour plots and three-dimensional surface response plots based on the equation taking two parameters at a time and keeping the other parameters at optimum. The effect of moisture and biosurfactant on lipase production are shown in figure $3 \mathrm{~A}$ and $3 \mathrm{~B}$ respectively. The biosurfactant at $1.25 \mathrm{mg}$ concentration and moisture at 50\% was contributing significantly towards production of 29.4 IU/g lipase from mustard cake. Nevertheless, the lipase production was affected at low moisture condition even if the biosurfactant was present at higher quantity, which establishes that the interaction between biosurfactant and moisture content was significant. In another experiment, by keeping moisture content and temperature at optimum, the influence and the possible interaction of $\mathrm{pH}$ and biosurfactant on lipase production was observed and presented in figure 4(A and $\mathrm{B})$. A strong influence of $\mathrm{pH}$ at different values was observed irrespective of the biosurfactant content on the highest lipase production showing the interaction of $\mathrm{pH}$ with biosurfactant. The most favorable conditions for $\mathrm{pH}$ and biosurfactant concentration were 8.3 and $1.2 \mathrm{mg}$ respectively. Under optimal conditions for biosurfactant and moisture content, the effect of other two process parameters (temperature, $\mathrm{pH}$ ) was also found out. Change in temperature had no effect on lipase production whereas $\mathrm{pH}$ was found to influence irrespective of variation in temperature (Fig. 5A and 5B). The highest lipase produced was $29.4 \mathrm{IU}$ at temperature $47^{\circ} \mathrm{C}$ and 
$\mathrm{pH}$ 8.3. Similar, effects of temperature $\left(35^{\circ} \mathrm{C}\right)$ and $\mathrm{pH}(8.5)$ on lipase production were observed using Pseudomonas aeruginosa employing Plackett-Burman design (PBD) for parameter optimization ${ }^{[28]}$. In contrast to our result, Khoramnia et al (2011) ${ }^{[29]}$ found that $\mathrm{pH}$ had not significant effect in process optimization for lipase production from Acinetobacter sp, while temperature plays important factor.

\section{Validation of the predicted model}

Central composite design model was employed to find out the best conditions of process parameters in order to maximize the production of lipase from mustard oil cake. The highest predicted lipase activity was found to be $29.4 \mathrm{IU} / \mathrm{g}$ at optimized conditions of $\mathrm{pH}$, temperature, moisture and biosurfactant respectively at $8.31,57.50{ }^{\circ} \mathrm{C}, 50 \%$ and $1.2 \mathrm{mg}$. Under the above conditions solid substrate lipase fermentation was carried out using mustard cake employing the thermophilic isolate Anoxybacillus sp. ARS-1 in order to experimentally validate the predicted model. The experimental lipase production was found to be at a near higher value $(30.3 \mathrm{IU} / \mathrm{g})$ as compared to the predicted value $(29.4 \mathrm{IU} / \mathrm{g})$ proving the goodness of fit of the model in predicting optimum enzyme production. It is further confirmed by Pearson's Chi-square test. The p value is $>0.05$, which indicates there is no significant difference between experimental and predicted lipase activity (Supplementary figure). Kai and Peisheng (2016) ${ }^{[30]}$ reported similar fitness of the prediction model for lipase production employing RSM using novel strain Thalassospira permensis.

\section{Effect of chemical and commercial detergents}

The compatibility and stability study of crude lipase was depicted in table. It was found that the crude lipase showed maximum activity in presence of non-ionic detergents like Tween 80 (107.6\%), Triton-X $100(99 \%)$ and Tween $20(83.6 \%)$ but activity was reduced to $48.3 \%$ in 
presence of ionic detergent SDS. Sajna et al. (2013) ${ }^{[31]}$ also reported that the activity of lipase from Pseudomonas sp. was increased in presence non-ionic detergents when compared with ionic detergents. Longer acyl ester chains of Tween 80 have favored lipase enzyme activity when compared to Tween $20^{[32]}$. Recently, Sahoo et al. (2019) ${ }^{[22]}$ reported that non-ionic detergent has low hydrophilic balance which might be enhancing the lipase activity. Lipase activity was found to be enhanced in presence of commercial detergents Ezee (104.3\%) and Ariel (103\%) but the activity was slightly decreased to $95.6 \%$ and $84.3 \%$ in presence of Surf excel and Ghadi detergents respectively. Saraswat et al. (2017) ${ }^{[33]}$ also reported similar influence of chemical as well as commercial detergents in his experiments using thermotolerant, alkalophilic lipase producing Bacillus subtilis isolate. In our findings, Anoxybacillus sp ARS-1 produced lipase was found to resist almost all chemical detergents as well as common laundry detergent, proving it to be a prospective additive for incorporation.

\section{Conclusion}

The industrially suitable thermostable $\left(57.50{ }^{\circ} \mathrm{C}\right)$ and alkaline stable $(\mathrm{pH}$ 8.31) isolate Anoxybacillus sp. ARS-1 obtained from Taptapani hotspring, The statistical model employed in the present work was found to be the best fitting and was validated by the experiment and thus can be utilized for pilot scale production of lipase from oil cake at an economic cost. Anoxybacillus sp. ARS-1 produced lipase was found to resist almost all chemical detergents as well as common laundry detergent, proving it to be a prospective additive for incorporation.

\section{Conflict of Interest}

The authors declare that they have no conflict of interest. 


\section{References}

[1] Colla, L. M.; Rizzardi, J.; Pinto, M. H.; Reinehr, C. O.; Bertolin, T. E.; Costa, J. A.V. Simultaneous production of lipases and biosurfactants by submerged and solid-state bioprocesses. Biores. Technol. 2010, 101(21), 8308-8314.

[2] Sanchez, S.; Demain, A. L. Enzymes and bioconversions of industrial, pharmaceutical, and biotechnological significance. Org. Proce. Res. Dev. 2011, 15, 224-30.

[3] Sharma, S.; Kanwar, S. S. Organic solvent tolerant lipases and applications. Sci. World J. $2014,625258,1-15$.

[4] Sahay, S.; Chouhan, D. Study on the potential of cold-active lipases from psychrotrophic fungi for detergent formulation. J. Gene. Eng. Biotechnol. 2018, 16(2), 319-325.

[5] Cherif, S.; Mnif, S.; Hadrich, F.; Abdelkafi, S.; and Sayadi, S. A newly high alkaline lipase: an ideal choice for application in detergent formulations. Lipids Health Dis. 2011, 10, 221.

[6] Rathi, P.; Saxena, R.; Gupta, R. A novel alkaline lipase from Burkholderia cepacia for detergent formulation. Proce. Biochem. 2001, 37, 187-92.

[7] Thirunavukarasu, K.; Edwinoliver, N. G.; Anbarasan, S. D.; Gowthaman, M. K.; Iefuji, H.; Kamini, N. R. Removal of triglyceride soil from fabrics by a novel lipase from Cryptococcus sp. S-2. Proce. Biochem. 2008, 43(7), 701-706.

[8] Hemlata, B.; Uzma, Z.; Tukaram, K. Substrate kinetics of thiol activated hyperthermostable alkaline lipase of Bacillus sonorensis 4R and its application in biodetergent formulation. Biocatal. Agric. Biotechnol. 2016, 8, 104-11.

[9] Adapa, V.; Ramaya, L. N.; Pulicherla, K. K.; Rao, K. Cold active pectinases: advancing the food industry to the next generation. App. Biochem. Biotechnol. 2014, 172, 2324-2337. 
[10] Alonso, F.; Oliveira, E.; Dellamora-Ortiz, G.; Pereira-Meirelles, F. Improvement of lipase production at different stirring speeds and oxygen levels. Braz. J. Chem. Eng. 2005, 22, 918.

[11] Kapoor, M.; Beg, Q. K.; Bhushan, B.; Singh, K.; Dadhich, K. S.; Hoondal, G. S. Application of an alkaline and thermostable polygalacturonase from Bacillus sp. MGcp-2 in degumming of ramie (Boehmeria nivea) and sunn hemp (Crotalaria juncea) bast fibres. Proce. Biochem. 2001, 36, 803-807.

[12] Kashyap, D. R.; Vohra, P. K.; Chopra, S.; Tewari, R. Applications of pectinases in the commercial sector: a review. Biores. Technol. 2001, 77, 215-227.

[13] Virupakshi, S.; Babu, K. G.; Gaikwad, S. R.; Naik, G. R. Production of a xylanolytic enzyme by a thermoalkaliphilic Bacillus sp. JB-99 in solid state fermentation. Proce. Biochem. 2005, 40, 431-435.

[14] Sabu, A.; Augur, C.; Swati, C.; Pandey, A. Tannase production by Lactobacillus sp. ASR-S1 under solid-state fermentation. Proce. Biochem. 2006, 41, 575-580.

[15] Aradhey, A. Oilseeds and Products Annual, USDA GAIN Report, IN7039, USDA'S Global Agriculture Information Network (GAIN). 2017.

[16] Echevarria, J.; Leon, JR.; Espinosa, M. E.; Delgado, G. Optimization of solid state fermentation of sugar cane by Aspergillus niger considering particles size effect. Acta. Biotechnologica. 1991, 11, 15-22.

[17] Pandey, A.; Benjamin, S.; Soccol, C. R.; Nigam, P.; Krieger, N.; Soccol, V. T. The realm of microbial lipases in biotechnology. Biotechnol. Appl. Biochem. 1999, 29, $119-31$. 
[18] Barrios-González, J.; González, H.; Mejía, A. Effect of particle size, packing density and agitation on penicillin production in solid state fermentation. Biotechnol. Adv. 1993, $11(3)$ 539-547.

[19] Liu, B. L.; Tzeng, Y. M. Water content and water activity for the production of cyclodepsipeptides in solid-state fermentation by Metarhizium anisopliae. Biotechnol. Lett. 1999, 21, 657-661.

[20] Elibol, M. Optimization of medium composition for actinorhodin production by Streptomyces coelicolor A3 with response surface methodology. Proce. Biochem. 2004, 39, 1057-1062.

[21] Soccol, C. R.; Brand, D.; Mohan, R.; Rodriguez, J. A. L.; Pandey, A. Coffee husk: a potential alternative material for bioprocesses. Meta. Mater. Proce. 2005, 17, 195.

[22] Sahoo, R. K.; Kumar, M.; Sukla, L. B.; Subudhi, E. Bioprospecting hot spring metagenome: Lipase for the production of biodiesel. Environ. Sci. Pollut. Res.

[232Altschul, SF.; Gish, W.; Miller, W.; Myers, EW.; Lipman, D. J. Basic local alignment search tool. J. Mol. Biol. 1990, 215, 403-410.

[24] Tamura, K.; Stecher, G.; Peterson, D.; Filipski, A.; Kumar, S. MEGA6: molecular evolutionary genetics analysis version 6.0. Mol. Biol. Evol. 2013, 30, 2725-2729.

[25] Olusesan, A.; Azura, L. K.; Abubakar, F.; Hamid, N. S. A.; Radu, S.; Saari, N. Phenotypic and molecular identification of a novel thermophilic Anoxybacillus species: a lipaseproducing bacterium isolated from a Malaysian hot spring. World J. Microbiol. Biotechnol. 2009, 25, 1981-1988. 
[26] Bakir, ZB.; Metin, K. Purification and characterization of an alkali-thermostable lipase from thermophilic Anoxybacillus flavithermus HBB 134. J. Microbiol. Biotechnol. 2016, 26(6), 1087-97.

[27] Ebrahimipour, G.; Sadeghi, H.; Zarinviarsagh, M. Statistical methodologies for the optimization of lipase and biosurfactant by Ochrobactrum intermedium strain MZV101 in identical medium for detergent application. Molecules 2017,22, 1460.

[28] Bisht, D.; Yadav, S. K.; Darmwal, N. S. An oxidant and organic solvent tolerant alkaline lipase by Pseudomonas aeruginosa mutant: downstream processing and biochemical characterization. Braz. J. Microbiol. 2013, 44(4), 1305-1314.

[29] Khoramnia, A.; Ebrahimpour, A.; Beh, B.K.; Lai, O.M. Production of a solvent, detergent, and thermotolerant lipase by a newly isolated Acinetobacter sp. In submerged and solid-state fermentations. J. Biomed. Biotechnol. 2011, 2011, 1-12.

[30] Kai, W.; Peisheng, Y. Optimization of Lipase production from a novel strain Thalassospira permensis M35-15 using Response Surface Methodology. Bioengineered $2016,7,298-303$.

[31] Sajna, K. V.; Sukumaran, R. K.; Jayamurthy, H.; Reddy, K.K.; Kanjilal, S.; Prasad, R.B.; Pandey, A. Studies on biosurfactants from Pseudozyma sp. NII 08165 and their potential application as laundry detergent additives. Biochem. Eng. J. 2013, 78, 85-92.

[32] Pooreydy, Golaki, B.; Aminzadeh, S.; Karkhane, A. A.; Yakhchali, B.; Farrokh, P.; Khaleghinejad, S. H.; Tehrani, A. A.; Mehrpooyan, S. Cloning, expression, purification, and characterization of lipase from thermophilic indigenous Cohnella sp. A01. Protein. Expr. Purif. 2015, 109, 120-126. 
[33] Saraswat, R.; Verma, V.; Sistla, S.; Bhushana, I. Evaluation of alkali and thermotolerant lipase from an indigenous isolated Bacillus strain for detergent formulation. Electr. J. Biotechnol. 2017, 30; 33-38. 


\section{Figure Captions}

Figure 1: Lipase production of bacterial strains isolated from the consortium.

Figure 2: Phylogenetic tree of 16S rRNA genes of lipase-producing bacteria was constructed by the neighbour-joining method using the MEGA6 software. One thousand bootstrap analyses were conducted. Scale bar $=0.01$ change per nucleotide position.

Figure 3: (A) Effect of biosurfactant and moisture on lipase production, (B) response surface graph showing interaction among them

Figure 4: (A) Effect of bio-surfactant and $\mathrm{pH}$ on lipase production, (B) response surface graph showing interaction among them.

Figure 5: (A) Effect of $\mathrm{pH}$ and temperature on lipase production, (B) response surface graph showing interaction among them.

Supplementary figure: (A) Comparison of experimental and predicted lipase activity. (B) Scatter plot of experimental vs predicted lipase activity. 
Figure 1: Lipase production of bacterial strains isolated from the consortium. $127 \times 76 \mathrm{~mm}(600 \times 600 \mathrm{DPI})$ 
Figure 2: Phylogenetic tree of 16S rRNA genes of lipase-producing bacteria was constructed by the neighbour-joining method using the MEGA6 software. One thousand bootstrap analyses were conducted. Scale bar $=0.01$ change per nucleotide position.

\section{$225 \times 92 \mathrm{~mm}(600 \times 600 \mathrm{DPI})$}




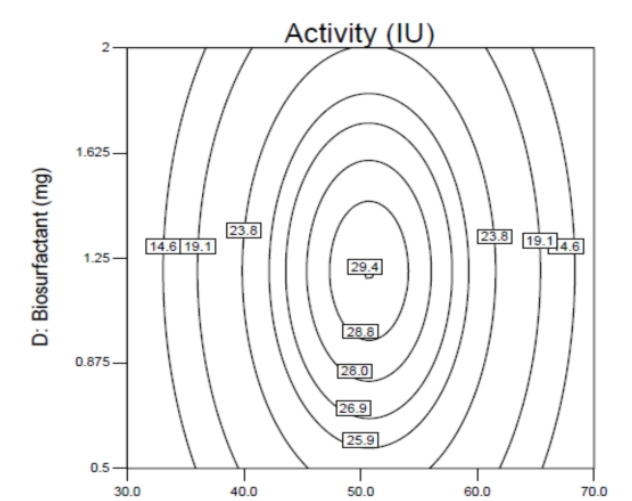

A

C: Moisture (\%)

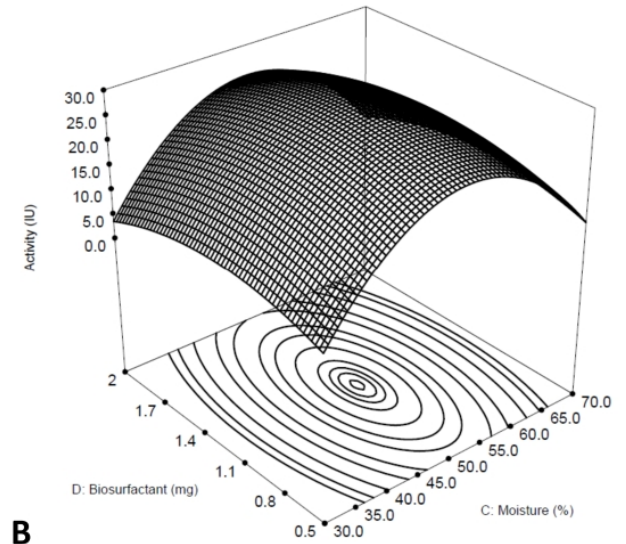

Figure 3: (A) Effect of biosurfactant and moisture on lipase production, (B) response surface graph showing interaction among them $303 \times 137 \mathrm{~mm}(600 \times 600 \mathrm{DPI})$ 

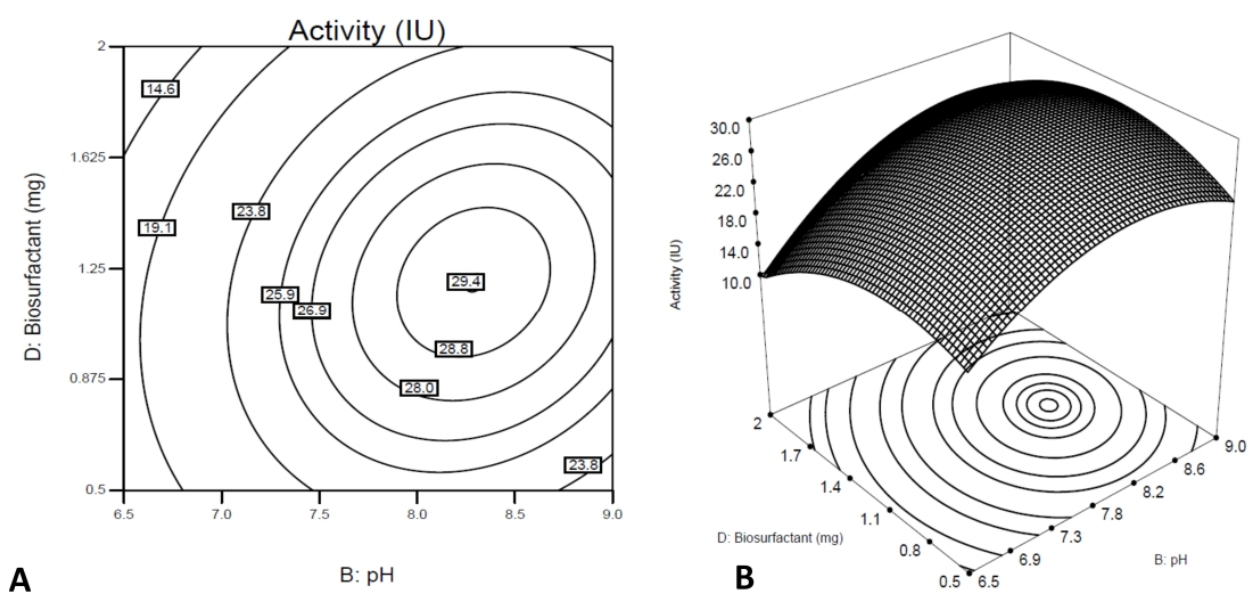

Figure 4: (A) Effect of bio-surfactant and $\mathrm{pH}$ on lipase production, (B) response surface graph showing interaction among them

$303 \times 139 \mathrm{~mm}(600 \times 600 \mathrm{DPI})$ 


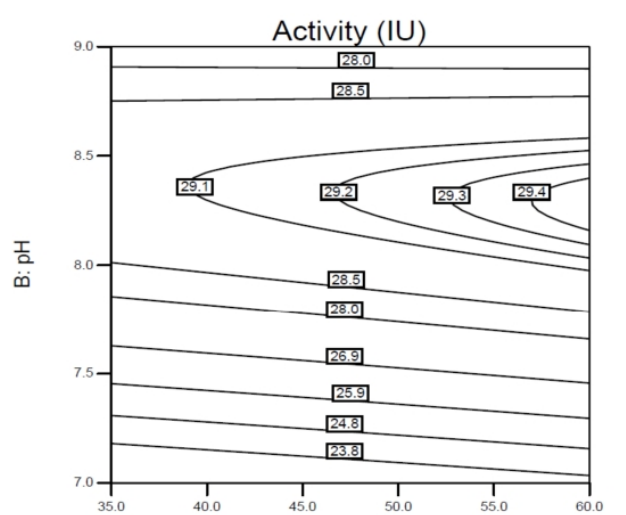

A

A: Temperature (C)



Figure 5: (A) Effect of $\mathrm{pH}$ and temperature on lipase production, (B) response surface graph showing interaction among them

$302 \times 138 \mathrm{~mm}(600 \times 600$ DPI $)$ 
Table S1: Variable parameters (independent variables) range and codes for their level

\begin{tabular}{|l|l|l|l|l|}
\hline \multirow{2}{*}{ Variables of the Process } & \multicolumn{2}{l|}{ Codes employed for Range and Level } \\
\cline { 3 - 6 } & Low (-1) & Medium (0) & High (+1) \\
\hline A & Temperature $\left({ }^{\circ} \mathrm{C}\right)$ & 35 & 50 & 65 \\
\hline B & $\mathrm{pH}$ & 7 & 8 & 9 \\
\hline C & Moisture (\%) & 30 & 50 & 70 \\
\hline D & Biosurfactant $(\mathrm{mg})$ & 0.5 & 1 & 1.5 \\
\hline
\end{tabular}


Table S2: Design of experiment using CCD for optimization of process parameters

\begin{tabular}{|c|c|c|c|c|c|c|c|}
\hline \multirow{3}{*}{$\begin{array}{l}\text { Run } \\
\text { order }\end{array}$} & \multirow{3}{*}{ Run Type } & \multicolumn{4}{|l|}{ Variables } & \multirow{2}{*}{\multicolumn{2}{|c|}{$\begin{array}{l}\text { Response (Y) } \\
\text { Lipase yield (IU/g) }\end{array}$}} \\
\hline & & \multirow{2}{*}{$\begin{array}{l}\text { biosurfactant } \\
\mathrm{mg}\end{array}$} & \multirow{2}{*}{$\begin{array}{l}\text { moisture } \\
\%\end{array}$} & \multirow{2}{*}{$\begin{array}{l}\text { temperature } \\
{ }^{\circ} \mathrm{C}\end{array}$} & \multirow[t]{2}{*}{$\mathrm{pH}$} & & \\
\hline & & & & & & Observed & Predicted \\
\hline 1 & Fact & 1.5125 & 60 & 42.5 & 9 & 20.78 & 23.01 \\
\hline 2 & Axial & 1.025 & 50 & 50 & 10 & 19.01 & 18.08 \\
\hline 3 & Fact & 0.5375 & 60 & 42.5 & 9 & 20.78 & 18.90 \\
\hline 4 & Center & 1.025 & 50 & 50 & 8 & 28.64 & 28.69 \\
\hline 5 & Center & 1.025 & 50 & 50 & 8 & 28.45 & 28.69 \\
\hline 6 & Axial & 1.025 & 50 & 50 & 6 & 10.34 & 10.20 \\
\hline 7 & Axial & 0.05 & 50 & 50 & 8 & 15.67 & 18.12 \\
\hline 8 & Center & 1.025 & 50 & 50 & 8 & 28.98 & 28.69 \\
\hline 9 & Center & 1.025 & 50 & 50 & 8 & 29.56 & 28.69 \\
\hline 10 & Axial & 2 & 50 & 50 & 8 & 24.8 & 22.74 \\
\hline 11 & Fact & 0.5375 & 40 & 42.5 & 9 & 15.76 & 17.54 \\
\hline 12 & Center & 1.025 & 50 & 50 & 8 & 27.9 & 28.69 \\
\hline 13 & Fact & 0.5375 & 40 & 42.5 & 7 & 15.45 & 15.10 \\
\hline 14 & Fact & 1.5125 & 60 & 42.5 & 7 & 16.63 & 16.67 \\
\hline 15 & Fact & 0.5375 & 40 & 57.5 & 9 & 16.43 & 17.27 \\
\hline 16 & Fact & 0.5375 & 60 & 57.5 & 9 & 20.52 & 18.63 \\
\hline 17 & Fact & 1.5125 & 40 & 42.5 & 7 & 13.56 & 15.31 \\
\hline 18 & Fact & 1.5125 & 40 & 57.5 & 7 & 14.56 & 16.23 \\
\hline 19 & Fact & 0.5375 & 60 & 57.5 & 7 & 18.23 & 17.09 \\
\hline 20 & Axial & 1.025 & 50 & 65 & 8 & 28.67 & 29.02 \\
\hline 21 & Fact & 1.5125 & 40 & 57.5 & 9 & 21.87 & 21.68 \\
\hline 22 & Center & 1.025 & 50 & 50 & 8 & 28.5 & 28.69 \\
\hline 23 & Fact & 1.5125 & 60 & 57.5 & 9 & 21.68 & 23.04 \\
\hline 24 & Axial & 1.025 & 30 & 50 & 8 & 9.59 & 8.35 \\
\hline 25 & Fact & 1.5125 & 40 & 42.5 & 9 & 22 & 21.65 \\
\hline 26 & Fact & 0.5375 & 40 & 57.5 & 7 & 16.27 & 15.73 \\
\hline 27 & Fact & 0.5375 & 60 & 42.5 & 7 & 17.89 & 16.47 \\
\hline 28 & Axial & 1.025 & 70 & 50 & 8 & 9.45 & 11.08 \\
\hline 29 & Fact & 1.5125 & 60 & 57.5 & 7 & 18.5 & 17.60 \\
\hline 30 & Axial & 1.025 & 50 & 35 & 8 & 28.94 & 28.37 \\
\hline
\end{tabular}


Table S3: ANOVA for Response Surface Quadratic Model [Partial sum of squares]

\begin{tabular}{|l|r|r|r|r|l|}
\hline Source & Sum of Squares & DF & \multicolumn{1}{l|}{$\begin{array}{l}\text { Sean } \\
\text { Square }\end{array}$} & F Value & Prob $>$ F \\
\hline Model & 3251.927 & 11 & 295.6298 & 150.8089 & $<0.0001$ \\
\hline A & 1.924068 & 1 & 1.924068 & 0.98152 & 0.3249 \\
\hline B & 279.3854 & 1 & 279.3854 & 142.5222 & $<0.0001$ \\
\hline C & 33.5517 & 1 & 33.5517 & 17.11565 & $<0.0001$ \\
\hline D & 95.88817 & 1 & 95.88817 & 48.9152 & $<0.0001$ \\
\hline A2 & 0.000043 & 1 & 0.000043 & 0.000022 & 0.9962 \\
\hline B2 & 1088.319 & 1 & 1088.319 & 555.1817 & $<0.0001$ \\
\hline C2 & 1852.421 & 1 & 1852.421 & 944.971 & $<0.0001$ \\
\hline D2 & 350.9202 & 1 & 350.9202 & 179.0141 & $<0.0001$ \\
\hline AB & 2.407552 & 1 & 2.407552 & 1.228159 & 0.2712 \\
\hline AD & 0.280602 & 1 & 0.280602 & 0.143143 & 0.7062 \\
\hline BD & 45.72755 & 1 & 45.72755 & 23.32688 & $<0.0001$ \\
\hline Residual & 152.9029 & 78 & 1.960294 & & \\
\hline Lack of Fit & 132.2704 & 13 & 10.17465 & 32.05391 & $<0.0001$ \\
\hline Pure Error & 20.63249 & 65 & 0.317423 & & \\
\hline Cor Total & 3404.83 & 89 & & & \\
\hline
\end{tabular}




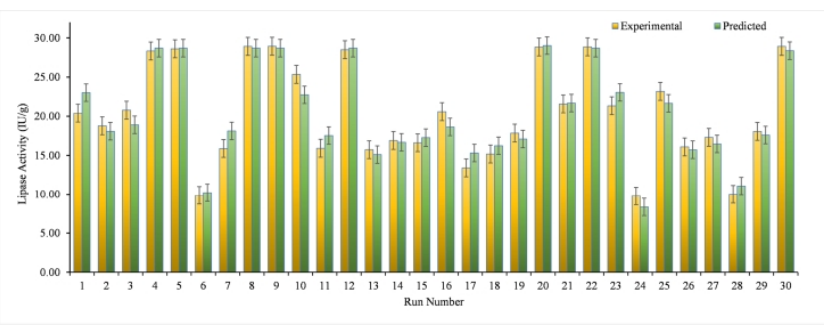

A

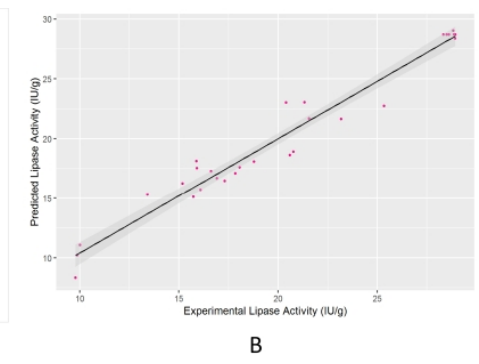

$437 \times 124 \mathrm{~mm}(300 \times 300$ DPI $)$ 
Table: Effect of chemicals and commercial detergents on stability of crude lipase from Anoxybacillus sp. ARS1

\begin{tabular}{ll}
\hline Detergents (1\% w/v) & Relative activity \\
\hline Control & 100.0 \\
SDS & $48.3 \pm 3.05$ \\
Tween 20 & $83.6 \pm 4.72$ \\
Tween 80 & $107.6 \pm 2.51$ \\
Triton X 100 & $99 \pm 4.58$ \\
Ezee & $104.3 \pm 2.51$ \\
Surf Excel & $95.6 \pm 3.51$ \\
Ghadi & $84.3 \pm 4.5$ \\
Ariel & $103 \pm 6.24$ \\
\hline
\end{tabular}

